This item was submitted to Loughborough's Research Repository by the author.

Items in Figshare are protected by copyright, with all rights reserved, unless otherwise indicated.

\title{
The effect of political connections on firm performance: evidence from Egypt
}

\section{PLEASE CITE THE PUBLISHED VERSION}

https://doi.org/10.1108/ARA-05-2020-0064

\section{PUBLISHER}

Emerald

\section{VERSION}

AM (Accepted Manuscript)

\section{PUBLISHER STATEMENT}

This paper was accepted for publication in the journal Asian Review of Accounting and the definitive published version is available at https://doi.org/10.1108/ARA-05-2020-0064.

\section{LICENCE}

CC BY-NC 4.0

\section{REPOSITORY RECORD}

Eissa, Aref, and Yasser Eliwa. 2021. "The Effect of Political Connections on Firm Performance: Evidence from Egypt”. Loughborough University. https://hdl.handle.net/2134/14828550.v1. 


\section{The Effect of Political Connections on Firm Performance: Evidence from Egypt}

\section{Aref M. Eissa and Yasser Eliwa}

Purpose - This paper examines the effect of political connections (PCs) on firms' profitability and market value in the Egyptian market after the uprising of 2013.

Design/methodology/approach - An empirical study is conducted based on 284 firm-year observations for non-financial listed firms on the EGX100 during the period of 2014-2017. To test our hypothesis, two independent sample t-test, Pearson correlation analysis and OLS regressions are conducted.

Findings - The results suggest that PCs are common across all industries in Egypt, the PCs through top officers do not improve firm's profitability; however, it has a positive effect on firms' market value. Further, PCs through business owners improve neither profitability nor the market value. Finally, the results suggest that PCs through government ownership have a positive effect on both firms' profitability and market value.

Research limitations/implications - Our finding encourages policymakers and regulators in emerging markets, e.g., Egypt, to develop stricter laws, policies, and regulatory initiatives to restrain the potential conflict of interest in the politically connected firms.

Originality/value - To the best of the authors' knowledge, this study is one of the first to examine the relationship between PCs and both profitability and market value in Egypt.

Keywords - Financial performance; Firm value; Political connections; Egypt.

Paper type Research paper 


\section{Introduction}

The financial performance of firms appears to be affected overwhelmingly by government policies (Adhikari et al., 2006). Thus, firms are expected to opt to enter into the political arena; to establish and promote good relations with politicians. These relations may include campaign contributions, friendships, family, and social networking (Faccio et al.,2006; Bliss and Gul, 2012; Blau et al., 2013; Correia, 2014). Further, firms may appoint former or current senior government officials or senior military and politicians on their boards to extract benefits from their connections (Chen et al., 2014; Jackowicz et al., 2014).

Under rent-seeking theory, firms use their resources to extract undeserved economic benefits from society without any wealth creation. These undeserved gains are a widespread form of political corruption (Smith, 2016). In this regard, Chen et al. (2011) suggest that firms establish political connections (PCs) for a number of reasons, such as (1) reducing the expropriation risk by the government; and (2) seeking additional government subsidies or avoiding optional fees. Interestingly, the pursuit of undeserved gains is common in emerging economies as well as in developed economies (Khwaja and Mian, 2011; Smith, 2016). Consequently, a number of previous studies examined the implications of PCs on firm's performance in both developed and emerging economies (e.g., Fisman, 2001; Faccio, 2006; Fan et al., 2007; Goldman et al., 2009; Boubakri et al., 2012a, b; Jackowicz et al., 2014; Wong and Hooy, 2018; Maaloul et al., 2018). They found that PCs significantly affect firm's performance, but the direction of this effect is still unclear.

Under the resource-based theory, a number of prior studies found that PCs reduce the expropriation risk by the government, receive more government subsidies, and getting exceptional treatment in gaining government contracts (Goldman et al., 2009; 2013; Chen et al., 2011; Khwaja and Mian, 2011; Wu et al., 2012a; Tahoun, 2014; Smith, 2016). Politically connected firms are also more likely to get long-term credit on concessional terms. Further, investors are considered these firms as less risky than non-connected firms, leading to a lower cost of capital (Xu et al., 2013; Boubakri et al., 2012b; Houston et al., 2014; 2017). In addition, during economic downturns or financial distress, connected firms are more likely to be rescued because PCs can affect capital allocation through financial aid mechanisms (Faccio et al., 2006; Blau et al., 2013). They are more likely to enter high entry barriers industries (Chen et al., 2014). They are also protected by regulatory authorities, which reduces the likelihood and enforcement costs (Correia, 2014). Moreover, they pay a lower tax (Kim and Zhang, 2016; Adhikari et al., 2006). Therefore, these politically connected firms have larger market shares (Faccio, 2010; Su and Fung, 2013), higher growth and productivity level (Du and Girma 2010), and better firm's profitability (Boubakri et al., 2012a; Maaloul et al., 2018). 
Under the reputation theory, PCs help firms to create a good reputation and achieve long-standing growth (Weigelt and Camerer, 1988). In this regard, prior studies found that politically connected firms have more substantial market power which leads to better market value than unconnected firms (Goldman et al., 2009; Boubakri et al., 2012b; Houston, 2014; 2017; Maaloul et al., 2018).

On the contrary, under agency theory, weak governance and poor law enforcement at the country level might raise agency problems and facilitate managerial rent extraction behaviours, which increase the cost of capital (Boubakri et al., 2012b). Consistent with this theory, some research confirmed that politically connected firms suffer from lower productivity (Faccio, 2010; Domadenik et al., 2015), lower profitability, higher cost of capital (Fisman, 2001; Fan et al., 2007; Bliss and Gul, 2012; Tu et al., 2013; Jackowicz et al., 2014) and usually pay lower dividends than other firms (Benjamin et al., 2016).

These conflicting views raise a question concerning the role of PCs on firms' performance and market value. Accordingly, a number of researchers argued that there was a positive effect of the PCs on profitability and firm's market value ( $\mathrm{Li}, 2008$; Goldman et al., 2009; Pérez et al., 2015; Bencheikh and Taktak, 2017; Maaloul et al., 2018). On the contrary, other researchers claimed that there is a negative effect of PCs on firms' profitability and market value (Fisman, 2001; Fan et al., 2007; Menozzi et al., 2011; Jackowicz et al., 2014; Cheema et al., 2016). However, Gilabert (2011) and Berkman and Galpoththage (2016) failed to find a convincing relationship between PCs and firm performance.

Our study extends this research and makes the following contributions to the literature. First, it investigates the effect of PCs on firm's performance in Egypt, as one of the largest emerging economies. While PCs practices are subject to the strength of the regulatory environment, most of the prior studies have been conducted in developed economies, characterized by low corruption levels and reliable legal systems. On the other hand, few studies test this relationship in emerging economies, which suffer from cronyism, corruption, informal relationships, and ineffective governance systems (Faccio, 2006; Maaloul et al., 2018) and find mixed results. These conflict results can be linked to the different settings in those countries, such as cultural dimensions settings, socio-political settings, and corporate governance effectiveness, which might limit our ability to generalize their results in other countries $(\mathrm{Li}$, 2008; Gilabert, 2011; Jackowicz et al., 2014; Cheema and Su, 2016).

In this regard, examining the mentioned relationship using a sample of Egyptian listed firms is essential. Egypt has started improving its democratic course and trying to fight corruption since the first uprising in 2011; however, corruption still a severe problem in Egypt today (Yingling and Arafa, 2013; Noll, 2019). After the second uprising, radical changes in the political setting in Egypt encourage more firms to enter into the political arena. The alliance between politicians and business becomes clearer when politicians enter as board members or 
shareholders and when business supports the election programs of the president and the targeted political candidates. This confirms the importance of checking the implications of PCs on the firm performance and market value to answer many fundamental questions, such as do firms benefit from PCs in Egypt? Do investors prefer to invest in politically connected firms, and whether PCs benefit firms and be favoured by investors? Therefore, we argue the Egyptian regulation and institutional environment provide an interesting setting for further exploration of PCs' financial consequences in Egypt as this topic has not been thoroughly investigated in the Egyptian context so far.

Second, we measure PCs using three different measures, which are politically connected firms through top officers $\left(\mathrm{PC}_{1}\right)$, through business owners $\left(\mathrm{PC}_{2}\right)$, and through government ownership ( $\left.\mathrm{PC}_{3}\right)$. This is important because prior studies demonstrate that there is no agreed measure to PCs, and the various measures used are not substitutes for each other (Wong and Hooy, 2018). Using the three abovementioned measures helps us to determine the impact of each measure on firm performance in Egypt. In this regard, the descriptive analysis of our sample shows that PCs are common across all industries in Egypt with $72.9 \%$ of our sample are connected through top officers, compared to $20.4 \%$ to our second measure of $\left(\mathrm{PC}_{2}\right)$, and $46.8 \%$ to our third measure $\left(\mathrm{PC}_{3}\right)$. These significant differences between the three measures provide insights into the relative importance and weight on each PCs measure in the Egyptian context.

Our results confirm that PCs through top officers do not improve the firm's profitability; however, it improves their market value. Further, PCs through business owners do improve neither firms' profitability nor market value. In comparison, the PCs through government ownership have a positive effect on both firms' profitability and market value. These results suggest that PCs through top officers and government ownership are essential for firm's reputation and success in emerging markets. Moreover, the results may not stir anxiety regarding the corruption that stems from PCs, where the politically connected firms through top officers or business owners do not benefit from PCs in the context of financial performance. However, we cannot assert this result as it needs more research to verify that politically connected firms do not engage in earnings management practices to reduce or smooth earnings to avoid suspicions of firm's corruption or to reduce taxes. Finally, politically connected firms through government ownership can get benefits and favour from their PCs. These findings have a broad impact as they might be applicable to the new democratic political systems in Africa and the Middle East, especially those suffering from political instability.

The remainder of this paper will be organized as follows: In section 2, we discuss the political connections in Egypt. In section 3, we review the literature and develop our research hypothesis. In section 4 , we outline the research methods. In section 5, we report our primary results. Finally, we conclude the paper. 


\section{Political Connections in Egypt}

Egypt has adopted a policy of economic reform since the early 1990s, the way in which these reforms were implemented contributed to cronyism; adopting an open-door policy in the mid-1970s by President Sadat provided an opportunity for selective businesspeople to enter these sectors. However, under President Mubarak regime, the elite of businessmen expanded. Those elite and their companies benefited from state withdrawal from some strategic sectors have expanded businessmen commercial interests since the 1990s (Sfakianakis, 2004). In the early 2000 s, acceleration of privatization in various sectors, the financial sector and trade reforms became the central policy in Egypt, and political connections evolved further and were coinciding with the political and economic role of the president's son, who held many central positions in the ruling party, as firms decided to connect with rising stars are more closely connected with Mubarak's son (Chekir and Diwan, 2013; Francis et al., 2018). Although the liberalization of the economy in many sectors, many barriers were erected to enter others. Politically connected firms were able to obtain governmental permission necessary to get privileges of these reforms. For example, they were able to create new factories in industries that characterized as energy-intensive, e.g., steel and cement, which needs government licenses. Also, they were able to import many goods that need pre-approval from the state. Cronyism flourished in the government headed by Ahmed Nazif from 2004 to 2011, where a group of political businessmen dominated the economy in Egypt. Politically connected firms have been able to take substantial control of the opportunities offered by the policy of economic liberalization in the construction of mega-projects, a number of manufacturing industries, telecommunications, banking as well as distributing international consumer brands domestically (Loewe, 2013; Francis et al., 2018).

On 25 January 2011, millions of Egyptian demonstrators gathered to protest against the Mubarak regime, who stepped down later on 11 February 2011. Power was handed over to the Supreme Council of Armed Forces until presidential elections in mid-2012. A few months later, Morsi became the next president. A new constitution was issued in December 2012, which promoted political Islam, and Morsi became increasingly undesirable with secular opposition. In the following months, Brotherhood's party tried to assert its power and control over the state's joints, leading to a new large-scale opposition movement, "Tamarud". Power was handed to an interim president, Adly Mansour, until elections were held and won by a former military commander in 2014.

After the fall of Mubarak, the trials of business leaders shed light on the fraud in the government systems and regulations by many politicians to stifle competition, accessing banks' loans on concessional terms by PCs, accessing outstanding energy subsidies, and acquiring government procurement contracts. It is obvious that Egypt has struggled for improving its democratic course and trying to fight corruption since the first uprising in 2011. However, the findings confirm that most trials of many prominent business people who were accused of fraud 
were terminated or ended, and several previous rulings were relaxed or revoked (Francis et al., 2018). In this regard, Chekir and Diwan (2013) document that PCs in Egypt allowed firms to increase their market size and power and their borrowings based on a sample of Egyptian firms before and after 201. Using a sample of connected firms during the period 2005-2013 to examine the implications of political connections through the Muslim Brotherhood, the Military and the (former) National Democratic Party (NDP), Acemoglu et al. (2018) document that firm value varied according to political events strengthening or weakening their political basis.

Accordingly, the severe changes that occurred after the January 2011 revolution and 30 June 2013 did not constrain political connections but strengthening or weakening the importance of PCs to firms. However, it is clear that PCs are still continuing strongly as a strategic policy by Egyptian firms to improve their performance (Yingling and Arafa, 2013; Acemoglu et al., 2018; Noll, 2019).

\section{Research Hypothesis Development}

Under the resource-based theory, politically connected firms may provide firms with several benefits such as access government resources easier, overcoming market barriers, and obtaining exceptional treatment by the government (Chen et al., 2014). Notably, in emerging economies, where private property rights in private firms are suffering from lack of protection according to inadequate law enforcement and the absence of market-supporting institutions for private firms (Wu et al., 2012a; Song et al., 2015). Accordingly, contracting with politically connected directors considered an effective way for firms to overcome their weaknesses at the state and market levels (Li et al., 2008). It also helps those firms get credit in concessional terms and lower rate (Xu et al., 2013), thereby mitigating any financial constraints to improve investment and innovation (Song et al., 2015). Moreover, connected firms may have competitive advantages over unconnected firms as they get exceptional treatment when procuring the governmental contracts (Goldman et al., 2009; 2013; Tahoun, 2014), be rescued during financial distress (Faccio et al., 2006; Blau et al., 2013), and pay a lower tax (Adhikari et al., 2006; Kim and Zhang 2016). This ultimately improves firms' profitability level (Li et al., 2008; Boubakri et al., 2012a; Ang et al., 2013; Su and Fung, 2013; Chen et al., 2014; Maaloul et al., 2018; Wong and Hooy, 2018). Moreover, Mohammed et al. (2017) find that PCs have negative consequences on earnings quality; however, the negative consequences may not be severe. Because the connected directors can bring more resources to their firms, they find a positive correlation between PCs and the firm's future performance.

Under the reputation theory, PCs are often useful to create a good reputation and to promote long-term gain (Weigelt and Camerer, 1988). The reputation of politically connected firms is a positive reaction to market failures and the law's weaknesses. In this regard, prior studies found that politically connected firms have more substantial market power and less risky than unconnected firms (Houston, 2014; 2017; Boubakri et al., 2012b), which help them to 
improve their market value (Lau and Tong 2008; Goldman et al., 2009; Ang et al., 2013; Su and Fung 2013; Pérez et al., 2015; Bencheikh and Taktak, 2017; Maaloul et al., 2018; Wang et al., 2018; Wong and Hooy, 2018). On the contrary, reputation risk may arise from some political events that harm firm value; for example, sudden death for politicians who are connected with firms will lead to a reduction in the firms market value. (Faccio and Parsley, 2009). For example, Fisman (2001) found that PCs in Indonesia are more sensitive to bad news regarding Suharto's health. Acemoglu et al. (2016) found that PCs may produce a positive abnormal stock return in the U.S, however announcing tax problems in politically connected firms lead to subsequently negative abnormal returns.

Additionally, under stakeholder theory, there are reciprocal benefits to be connected with the politicians, the connected firms are expected to gain benefits to maximize stakeholders' wealth, at the same time they bear the costs according to contributing to politicians' campaigns and the achievement of their electoral programs (Cooper et al., 2010; Tahoun, 2014). Accordingly, considering politicians rent extractions, improvement in the firm value will happen if the marginal benefits of the PCs outweigh their marginal costs (Shleifer and Vishny, 1994; Faccio, 2006; Bencheikh and Taktak, 2017). For example, Bertrand et al. (2018) found that politically connected firms in France are less profitable compared to unconnected firms, especially in politically contested areas and in election years. The study explained this lower in profits due to the increase in job opportunities during the election period, which aims to achieve the largest number of votes in favour to help the current politicians in their re-election. Moreover, connected CEOs may be deceived as they grant politicians some favours to personally benefit from it. Nevertheless, politicians do not return favours as expected, which is consistent with the view that politicians give CEOs the illusion of power, who probably buy this illusion. These results are also confirmed by Menozzi et al. (2011), who found that politically connected directors in Italian firms exert a significant positive effect on employment and have a negative effect on firm performance.

In addition, agency theory hypothesizes that political connections may facilitate managerial rent extractions. Faccio (2010) confirms that PCs are more likely to engage in managerial rent extractions, which deteriorate firm value, especially in more corrupt countries. Accordingly, connected firms may suffer from bad management and inefficiency (Shleifer and Vishny, 1994), as they appoint bureaucrats to the board of directors rather than directors with relevant professional backgrounds (Fan et al., 2007), or these firms are more likely to exhibit excessive tunnelling (Tu et al. (2013). Accordingly, politically connected firms may exhibit lower profitability compared to the unconnected firm (Faccio et al., 2006; Fan et al., 2007; Tu et al., 2013; Jackowicz et al., 2014; Cheema et al., 2016; Bertrand et al., 2018). In the same direction, some empirical research confirms that PCs suffer from higher asymmetric information due to lower earnings quality and lower analysts' accuracy in PCs (Chen et al., 2010; Chaney et al., 2011). This ultimately increases the cost of capital for these firms and decrease their market value 
(Bliss and Gul, 2012). Besides, some empirical research fails to find any relationships between PCs and firm value (Gilabert, 2011; Berkman and Galpoththage, 2016).

In Egypt, which still suffering from high levels of corruptions, severe changes that occurred after the January 2011 revolution and 30 June 2013 did not add real value in investor protection and governance systems, and PCs are still used as a strategic policy by firms to improve their financial performance (Acemoglu et al., 2018; Noll, 2019). We expect that firms are building political connections to overcome market barriers, access government resources easier, and obtain exceptional treatment by the government in Egypt, which might improve their financial performance. In addition, these connections would create a good reputation and promote long-term gain that enhances firms' market value. We predict positive relationships between PCs and firms' performance and market value in Egypt. Consequently, our research hypotheses would be as follow:

H1: In Egypt, there is a positive relationship between PCs and firms' financial performance.

H2: In Egypt, there is a positive relationship between PCs and firms' market value.

\section{Research Design}

\subsection{Sample and Data Sources:}

The sample consists of large firms listed on the Egyptian Stock Exchange (EGX). Financial and Insurance firms are excluded due to their specific characteristics. Due to the data that has been missed for some firms, a number of observations were excluded. In this regard, the final sample was 71 non-financial firms spanning the period from 2014 to 2017. This results in 284 firm-year observations. Table (1) shows the sample selection process and final sample distribution by sector.

Data has been collected from many sources; accounting and financial data are collected from annual reports and EGX Archive. The data regarding PCs are manually collected from different sources. List of executives, board members, chairmen, and large Shareholders names are collected from the annual reports and board of directors' reports. These names are searched from several sources. First, there are profiles of the firm's top officers available on their annual reports or websites. These profiles provide some information regarding the current or former position of those officers in the government, the military, political parties, or policy-making organizations. Second, the website of the Egyptian parliament provides names of current parliament members. Third, the Egyptian Government Office website provides names of all prime minister in Egypt since 1940. Fourth, we searched by name in Google search engine to collect data about those top officers in different newspaper websites such as Al-Ahram, Al- 
Akhbar, Almasry Alyoum, Youm7, and other rebuttable newspapers. Finally, all personal data that have been collected from these websites regarding officers, directors, and large Shareholders were verified and matched from multiple sources.

\section{[Insert Table 1 here]}

\subsection{Variable Measurement}

\section{Dependents Variables}

This study uses two dependent variables, which are firm performance and market value. Firm performance is measured using two measures, which are return on assets $(R O A)$ and return on equity ( $R O E)$. ROA is measured as the net income before extraordinary items divided by total assets. $R O E$ is measured using the net income before extraordinary items divided by the book value of owners' equity. To measure market value of firms, Tobin's $Q$ is used, which is calculated as the natural logarithm of the ratio of market value of the firm to the book value of total assets of this firm (Ang et al., 2013; Su and Fung, 2013; Pérez et al., 2015; Maaloul et al., 2018).

\section{Independent Variables}

PCs are used in this study as independent variables. Wong and Hooy (2018) emphasize the importance of differentiation between the different types of PCs, as not all PCs contribute to firm value. This study uses three common proxies of PCs. (1) politically connected firms through top officers $\left(\mathrm{PC}_{1}\right)$, which is measured using a dummy variable equals to 1 if one of the top officers (e.g., a chairman, a secretary, a member in the board of directors, or a CEO) is one of a current "former" of top government officials (e.g. a minister, a member of the national parliament, or senior military personnel), a member of a political party, or has family ties with those politicians and 0 otherwise (Faccio,2006; Fan et al., 2007; Su and Fung, 2013; Ang et al., 2013; Maaloul et al., 2018). (2) Politically connected firms through business owners ( $\left.\mathrm{PC}_{2}\right)$, which is measured using a dummy variable equals to 1 if one of the large shareholders in the firm (who controlling at least $10 \%$ of voting rights) is a current or former of top government officials (e.g. a minister or a member of the national parliament or senior military personnel), a member of a political party, or has family ties with politicians and 0 otherwise (Faccio, 2006; Berkman and Galpoththage, 2016; Wong and Hooy, 2018; Chung et al., 2019). (3) Politically connected firms through government ownership $\left(\mathrm{PC}_{3}\right)$, which is measured using a dummy variable equal to 1 if the government controls at least $10 \%$ of firm shares and 0 otherwise $(\mathrm{Wu}$ et al., 2012a; Su and Fung 2013; Ang et al., 2013; Wong and Hooy, 2018). 


\section{Control Variables}

A number of control variables are used in this study, such as firm size (Size), firm leverage $(L E V)$, and firm growth (Growth). Size is calculated using the natural logarithm of total assets (Boubakri et al., 2012a; Jackowicz et al., 2014; Wong and Hooy, 2018). LEV is calculated using the ratio of total debt to total assets (Wong and Hooy, 2018; Maaloul et al., 2018). Growth is calculated using the percentage change in sales in the current year compared to last year (Cheema et al., 2016; Wang et al., 2018; Wong and Hooy, 2018). Finally, industry and year effects are used in the main models (Pérez et al., 2015; Maaloul et al., 2018).

\subsection{Empirical Models}

our study depends on the following models to test the effect of PCs on firm's profitability and market value. These models are widely used in previous studies to examine the effect of PCs and firm's profitability and market value (e.g., Faccio et al., 2006; Wu et al., 2012b; Su and Fung, 2013; Maaloul et al., 2018; Wong and Hooy, 2018). Equation (1) is used to examine the relationship between PCs and firm performance. Equation (2) is used to examine the relationship between PCs and firm's market value.
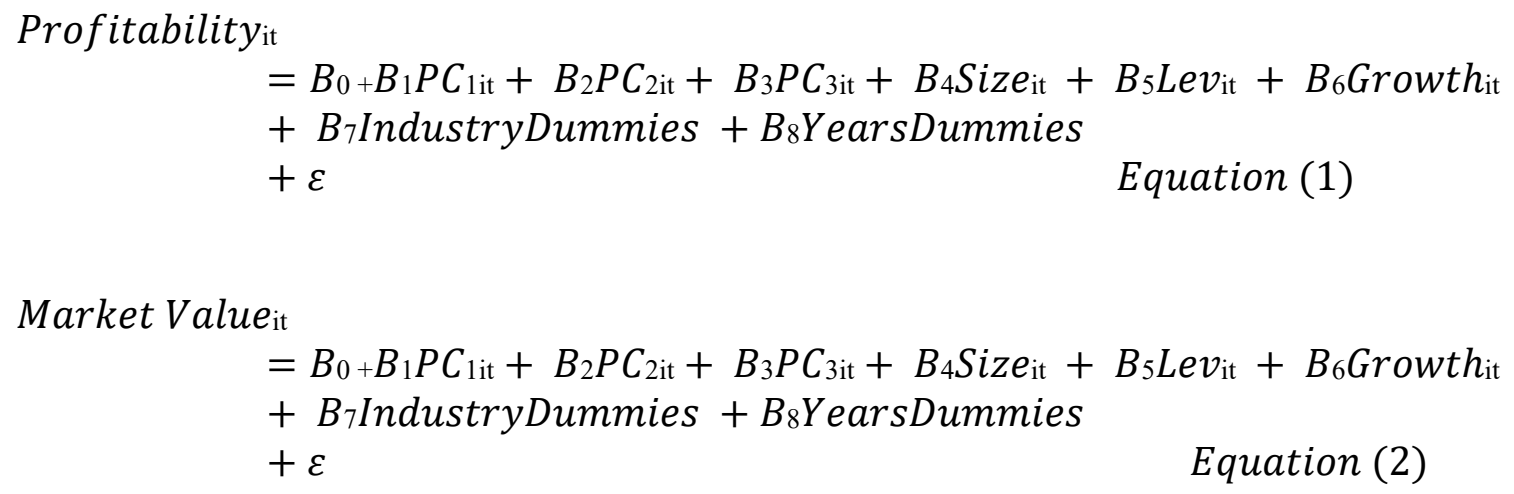

Where profitability is measured using $R O A$ and $R O E$. Market value is measured by Tobin's $Q . \mathrm{PC}_{1}$ is the first type of PCs measured through the board of directors or executive's connections. $\mathrm{PC}_{2}$ is the second type of connections measured through the business owners' connections. $\mathrm{PC}_{3}$ is the third type of connections measured through governmental ownership. Size is measured using the natural logarithm of total assets. LEV is measured as total debts divided by total assets. Growth is the percentage of sales change. Tables (2) shows the definitions of all variables used in this study.

[Insert Table 2 here] 


\section{Empirical Tests and Results}

\subsection{Descriptive Statistics}

Table 3 shows descriptive statistics of the sample firms based on PCs type, year, and industry. Panel A of Table 3 shows that there are 207 observations (72.9\% of the sample) are connected through top officers ( $\left.\mathrm{PC}_{1}\right), 58$ observations (20.4\%) are connected through business owners $\left(\mathrm{PC}_{2}\right)$, and 133 observations $(46.8 \%)$ are connected through government ownership $\left(\mathrm{PC}_{3}\right)$. Finally, there are $23(8 \%)$ are unconnected to any type of political connections. These results confirm that the percentage of Egyptian politically connected firms is significant. Also, it confirms that the first kind of $\mathrm{PCs}\left(\mathrm{PC}_{1}\right)$ is the more common type in the sample. This result may reflect that firms in Egypt may prefer to be connected through top officer $\left(\mathrm{PC}_{1}\right)$ more than connected through business owners $\left(\mathrm{PC}_{2}\right)$ or may reflect that politicians prefer to work as top officers rather than to be business owners.

Panel B in Table 3 shows that the percentage of connected firms by year. It shows that the percentage of connected firms in the sample does not change significantly across the study period. The percentages of $\mathrm{PC}_{1}$ during the period are $70.42 \%, 71.83 \%, 74.65 \%$, and $74.65 \%$, respectively. The percentages of $\mathrm{PC}_{2}$ during the period are $19.72 \%, 21.13 \%, 21.13 \%$, and $19.72 \%$, respectively, and the percentages of $\mathrm{PC}_{3}$ during the period are $46.48 \%, 46.48 \%$, $46.48 \%$, and $47.89 \%$, respectively. The higher percentage of connected firms and stability in the percentage across the study period could be explained by the stability in the political scene after the second uprising 30 June 2013, which drive firms to establish continuously political connections ( $\mathrm{Lu}$ and Choi 2013).

Panel C confirms that PCs spread across all industries and firms in many cases have more than one kind of PCs, this may reflect firm's conviction for the importance of PCs as a strategy that could improve their performance and value in Egypt (Li et al., 2008; Goldman et al., 2009; Xu et al., 2013; Chen et al., 2014; Faccio et al., 2006). These results are also consistent with Fisman (2001); Faccio (2006), who argue that PCs are more common and serious in emerging economies according to imperfect formal institutions, such as weak investor protection systems, low legal enforcement, and Ineffectiveness of corporate governance systems.

\section{[Insert Table 3 here]}

Table 4 provides preliminary statistics variance between connected and unconnected firms in the sample. Panel A in Table 4 confirms that politically connected firms through top officers $\left(\mathrm{PC}_{1}\right)$ have higher $R O A$, lower $R O E$, and higher Tobin's $Q$ than unconnected firms. However, these differences are insignificant. The results also show that the size of connected 
firms through top officers $\left(\mathrm{PC}_{1}\right)$ is significantly larger than unconnected firms. Panel B in Table 4 shows that connected firms through business owners $\left(\mathrm{PC}_{2}\right)$ have insignificantly higher $R O A$, significantly lower $R O E$ (at 5\% level) and significantly higher Tobin's $Q$ (at 1\% level) than those unconnected. The results also show that the size of connected firms through business owner is significantly larger (at $1 \%$ level) than the size of unconnected firms.

Panel $\mathrm{C}$ in Table 4 shows that firms with government ownership $\left(\mathrm{PC}_{3}\right)$ have significantly higher $R O A$ (at $10 \%$ level), higher $R O E$ (at 1\% level) and higher Tobin's $Q$ (at $5 \%$ level) than unconnected firms. The results also show that the size of $\mathrm{PC}_{3}$ firms is insignificantly larger than unconnected firms. However, the leverage level of $\mathrm{PC}_{3}$ firms is significantly higher (at the 10\% level) than the leverage of unconnected firms.

The preliminary results indicate that PCs through top officers $\left(\mathrm{PC}_{1}\right)$ do not contribute to firms' profitability or market value. The PCs through business owners $\left(\mathrm{PC}_{2}\right)$ have a lower return on equity and lower market value. However, the results confirm that PCs through government ownership $\left(\mathrm{PC}_{3}\right)$ contribute to better profitability and market value.

\section{[Insert Table 4 here]}

\subsection{Correlation Analysis}

Table 5 shows the Pearson correlations between the primary variables of this study. As shown in the table, the politically connected firms through top officers $\left(\mathrm{PC}_{1}\right)$ are not correlated to profitability ( $R O A, R O E$ ) or firm value (Tobin's $Q$ ). The politically connected firms through business owners $\left(\mathrm{PC}_{2}\right)$ negatively correlate with $R O E$ and Tobin's $Q$ at the $5 \%$ and $1 \%$ levels, respectively. The politically connected firms through government ownership $\left(\mathrm{PC}_{3}\right)$ have a positive correlation with profitability measures ( $R O A$ and $R O E)$ and firm value (Tobin's $Q$ ) at $10 \%, 1 \%$ and $1 \%$ levels, respectively. These results primarily support the prediction the effect of PCs on firms' profitability and the market value may vary according to PCs type.

Moreover, Table 5 shows that PCs through top officers ( $\left.\mathrm{PC}_{1}\right)$ are correlated positively to Size, at the 5\% level. Also, PCs through business owners $\left(\mathrm{PC}_{2}\right)$ are correlated positively to Size, at the $1 \%$ level. However, PCs through government ownership $\left(\mathrm{PC}_{3}\right)$ are not correlated to Size. This confirms that politicians are more likely to join large firms to be benefited from the advantages of the size of these firms. Further, the results confirm a negative correlation between $\mathrm{PC}_{1}$ and $\mathrm{PC}_{3}$ at $1 \%$ level. The results also confirm a negative correlation between $\mathrm{PC}_{2}$ and $\mathrm{PC}_{3}$ at $1 \%$ level. These findings indicate that private firms trying to get protected through PCs alliance while governmental firms already protected and do not need to connect through top officers or business owners. Finally, the results confirm that only firms with government ownership $\left(\mathrm{PC}_{3}\right)$ are highly leveraged $(L E V)$. This result is significantly at a $10 \%$ level. 
Regarding the multicollinearity problem, the correlation matrix shows low correlations between the studied variables. We also used the Variance Inflation Factor (VIF) test and found that all the VIFs scores are less than two, indicating no multicollinearity between our independent variables. These tests support that there is no possibility of a multicollinearity problem in the dataset (Wang et al., 2018; Maaloul et al., 2018).

\section{[Insert Table 5 here]}

\subsection{Regression Analysis}

Table 6 shows the results of regressing different types of PCs on firms' profitability and market value. columns 1-2 of the table show an insignificant positive effect of $\mathrm{PC}_{1}$ on $R O A$ ( $\beta$ $=0.001, \mathrm{p}>0.1)$, and $R O E(\beta=0.003, \mathrm{p}>0.1)$. This result indicates that PCs through top officers do not contribute to firm's profitability, which is consistent with a number of previous studies that did not find any relationship between PCs through top officers and firm's profitability (e.g., Gilabert, 2011; Berkman and Galpoththage, 2016). This leads to a rejection of the first hypothesis $\left(\mathrm{H}_{1}\right)$. However, the results show a significant positive effect of $\mathrm{PC}_{1}$ on Tobin's $Q(\beta=0.220, \mathrm{p}<0.05)$, which is consistent with previous studies that find a positive effect of PCs on firm's market value (e.g., Goldman et al., 2009; Su and Fung, 2013; Pérez et al., 2015; Wong and Hooy, 2018). These results support our second hypothesis $\left(\mathrm{H}_{2}\right)$. The positive effect of $\mathrm{PC}_{1}$ on the firm's market value might indicate the tendency of investors to invest in politically connected firms through top officers to benefit from the expected advantages, or they might expect that these firms are less risky, which is consistent with the reputation theory, which is confirmed by Goldman et al. (2009) and Boubakri et al. (2012a).

The results also confirm that $\mathrm{PC}_{2}$ has an insignificant positive effect on $R O A(\beta=0.001$, $\mathrm{p}>0.1$ ). However, it has an insignificant negative effect on $R O E$ and Tobin's $Q$ ( $\beta=-0.007$, $-0.069, \mathrm{p}>0.1$ ), respectively. These results indicate that PCs through ownership do not contribute to firm's profitability or firm's market value. These results are consistent with Wong and Hooy (2018), who did not find any relationship between PCs through business ownership and firm's performance. These results do not support the first hypothesis $\left(\mathrm{H}_{1}\right)$.

According to politically connect firms through government ownership $\left(\mathrm{PC}_{3}\right)$, the results confirm that $\mathrm{PC}_{3}$ has a highly significant positive effect on $R O A(\beta=0.032, \mathrm{p}<0.01)$ and $\mathrm{ROE}$ $(\beta=0.083, \mathrm{p}<0.01)$. In addition, $\mathrm{PC}_{3}$ has a highly significant positive effect on Tobin's $Q(\beta$ $=0.227, \mathrm{p}<0.01)$. These results indicate that PCs through government ownership contribute to firm's profitability and improve their market value, which is consistent with Lau and Tong (2008) and Wong and Hooy (2018). Thus, the results support our first $\left(\mathrm{H}_{1}\right)$ and second hypothesis $\left(\mathrm{H}_{2}\right)$. 
Considering the control variables, the results confirm that Size has a significant positive effect on $R O A(\beta=0.014, \mathrm{p}<0.01)$ and $\operatorname{ROE}(\beta=0.017, \mathrm{p}<0.01)$. However, it has a negative effect on Tobin's $Q(\beta=-0.056, \mathrm{p}<0.05)$. These results are consistent with the fact that larger Egyptian firms show better profitability. However, it imposes agency problems that negatively reflected on the market value of the firm (Tobin's $Q$ ), which is consistent with previous studies (e.g., Pérez et al., 2015; Maaloul et al., 2018). Moving to $L E V$, it shows mixed results. It has a significant negative effect on $R O A(\beta=-0.074, \mathrm{p}<0.01)$, however, it has a significant positive effect on $\operatorname{ROE}(\beta=0.211, \mathrm{p}<0.01)$ and Tobin's $Q(\beta=0.841, \mathrm{p}<0.01)$. Moving to Growth, the results show insignificant negative effects of Growth on $R O A(\beta=-0.011, \mathrm{p}>0.1)$ and $R O E(\beta=-0.029, \mathrm{p}>0.1)$, but it has a significant positive effect on Tobin's $Q(\beta=0.142, \mathrm{p}<$ 0.10). These results are consistent with the previous studies (e.g., Maaloul et al., 2018).

\section{[Insert Table 6 here]}

\subsection{Robustness tests}

\subsubsection{PCs, ROS, and MTB Ratio}

Table 7 shows the results of regressing PCs on profitability measured by return on sales (ROS) (Fan et al., 2007; Jackowicz et al., 2014), and the market value of the firm measured by Market to Book Ratio (MtB) (Boubakri et al., 2018). The results show an insignificant positive effect of $\mathrm{PC}_{1}$ on $\operatorname{ROS}(\beta=-0.017, \mathrm{p}>0.1)$. However, it has a significant positive effect on $\mathrm{MtB}$ ratio $(\beta=0.312, p<0.10)$. These results indicate that PCs through top officers do not contribute to firm's profitability; however, it improves firm's market value. Results also show an insignificant positive effect of $\mathrm{PC}_{2}$ on $\operatorname{ROS}(\beta=0.013, \mathrm{p}>0.1)$, and $\mathrm{MtB}$ ratio $(\beta=0.026, \mathrm{p}>$ 0.1 ), which implies that PCs through shareholders do not contribute to firm's profitability or firm value. Finally, the results show a significant positive effect of $\mathrm{PC}_{3}$ on $\operatorname{ROS}(\beta=0.070, p$ $<0.01)$ and MtB ratio $(\beta=0.439, \mathrm{p}<0.01)$. These results indicate that PCs through governmental ownership contribute to firms' profitability and improves firms' market value.

\section{[Insert Table 7 here]}

\subsubsection{The moderating effects of political connections through top officers}

In this section, we test the moderating effects of political connections through top officers $\left(\mathrm{PC}_{1}\right)$ on the relationship between political connections through government ownership $\left(\mathrm{PC}_{3}\right)$ and both firms' profitability and market value. We add the interaction term $\left(\mathrm{PC}_{1} * \mathrm{PC}_{3}\right)$ to the main models and re-run the tests. Table 8 reports the results, which shows that the coefficient of 
$\mathrm{PC}_{1} * \mathrm{PC}_{3}$ is significantly positive. This suggests that governmental firms that hires politicians in top positions have better firm performance than other governmental firms.

Moving to the market value model (Tobin's $Q$ ), our results indicate that those governmental firms that have politicians in top positions having better market value than other governmental firms. These findings support the argument that having political connections in the management and the ownership (government type) in firms will make them in a better financial position compared to other firms.

\section{[Insert Table 8 here]}

\subsubsection{Endogeneity Test}

One potential issue for the OLS regressions is that the PCs dummy variables might not be exogenous. Specifically, some unobserved factors of profitability and firm's market value may also explain PCs, leading OLS estimates to be inconsistent and biased. Depending on the 2SLS method, three instrumental variables as well as the other independent variables regressing in the first stage of the 2SLS method to estimate the different types of PCs, these variables are, firm age, which measured as a natural logarithm of firm age (Boubakri et al., 2012b; Bencheikh and Taktak, 2017), lagged of market capitalization ( $\operatorname{Lag} M C$ ) which is calculated as multiplying the number of shares outstanding by the share price at year-end (Faccio et al., 2006; Goldman et al., 2009; Maaloul et al., 2018) and lagged return on assets (Lag ROA) (Maaloul et al., 2018), then the fitted values for different PCs types are used in the second stage of OLS regression. Results show similar results to the main results of the OLS regression (results reported in Table 9). These results indicate that it is not likely that our main evidence is driven by endogeneity concerns.

\section{[Insert Table 9 here]}

\section{Conclusion and Future Research}

Previous research confirms that political connections should be considered because these connections may result in mutual benefits between business and politicians, e.g., supporting election campaigns to achieve electoral programs for politicians. This gives firms an opportunity to access government contracts and access state resources illegally or at low prices. Accordingly, this study aims to investigate the effect of PCs profitability and market value of firms in Egypt after the second uprising on 30 June 2013 using a sample of 284 nonfinancial firms listed on the Egyptian Stock Exchange. We find that PCs are common across all industries in Egypt, which is consistent with Faccio (2006), who claim that ineffective governance systems, weak legal systems, and high levels of corruptions contribute to a fertile environment and encourage building PCs (Faccio 2006). Our results also show a negative relationship between PCs through government ownership ( $\left.\mathrm{PC}_{3}\right)$ and both $\mathrm{PCs}$ through top 
officers $\left(\mathrm{PC}_{1}\right)$ and through business owners $\left(\mathrm{PC}_{2}\right)$, which confirms that governmental firms already protected and do not need to be connected through top officers or business owners, while private firms are trying to get protected through PCs alliance. Moreover, our results indicate that PCs types contribute differently to firms' profitability and market value. This finding supports our argument of the importance of using different types of PCs in the same analysis and being sensitive in explaining the results based on the type of PCs. For example, we find that PCs through top officers do not improve firm's profitability; which is inconsistent with resource-based theory; however, it improves firm's value, which is consistent with reputation theory (Goldman et al., 2009; Su and Fung, 2013; Pérez et al., 2015; Wong and Hooy, 2018). We also find PCs through business owners $\left(\mathrm{PC}_{2}\right)$ improve neither firm's profitability nor market value, which is consistent with the results of Wong and Hooy (2018). These findings could be explained as politically connected firms through business owners have a weaker resource base and are less stable as they are connected to one influential politician. Finally, our results shows that PCs through government ownership have a positive impact on both firms' profitability and market value, which is consistent with both resource-based and reputation theories (Lau and Tong, 2008; Wong and Hooy, 2018).

Our study has a number of theoretical and practical implications that are relevant to academics, policymakers, regulators, and financial markets participants in emerging markets. Theoretically, our study contributes to the enrichment of PCs literature regarding the relationship between politicians and business in the Egyptian context as an example of an emerging economy. Practically, our results show that PCs do not contribute significantly to firms' financial performance. This finding encourages policymakers and regulators in emerging markets, e.g., Egypt, to develop stricter laws, policies, and regulatory initiatives to restrain the potential conflict of interest in these firms. For capital market participants, e.g., investors, our results provide evidence the PCs through top officers and through shareholdings do not contribute to firms' profitability in Egypt. This is important for retail investors when they mainly plan for their future investments.

The limitations of this study are as follows; first, PCs through friendship are not included as the data are not available on the personal friendship for every firm. Second, examining the PCs as a dummy variable equals to 1 if the firm has any kind of the different PCs type and 0 otherwise was not possible since most of the firms that used in the sample are PCs. Future research may be extending this research by investigating the interactions between PCs and corporate governance mechanisms on firms' profitability and market value.

\section{Acknowledgements}

We are thankful for the constructive and stimulating comments received from Dr Wenxia Ge (the associate editor) and two anonymous reviewers. Any remaining errors are the authors' own. 


\section{References}

Abdul Wahab, E.A., Ariff, A.M., MadahMarzuki, M. and Mohd Sanusi, Z. (2017), "Political connections, corporate governance, and tax aggressiveness in Malaysia", Asian Review of Accounting, Vol. 25 No. 3, pp. 424-451.

Acemoglu, D., Hassan, T. A. and Tahoun, A. (2018), "The power of the street: evidence from Egypt's Arab Spring”, The Review of Financial Studies, Vol. 31 No. 1, pp. 1-42.

Acemoglu, D., Johnson, S., Kermani, A., Kwak, J. and Mitton, T. (2016), "The value of connections in turbulent times: evidence from the United States", Journal of Financial Economics, Vol. 121 No. 2, pp. 368-391.

Adhikari, A., Derashid, C. and Zhang, H. (2006), "Public policy, political connections, and effective tax rates: longitudinal evidence from Malaysia", Journal of Accounting and Public Policy, Vol. 25 No. 5, pp. 574-595.

Ang, J. S., Ding, D. K. and Thong, T. Y. (2013), "Political connection and firm value", Asian Development Review, Vol. 30 No. 2, pp. 131-166.

Bencheikh, F. and Taktak, N. B. (2017), "The effect of political connections on the firm performance in a newly democratized country", Mediterranean Journal of Social Sciences, Vol. 8 No. 4, pp. 40-46.

Benjamin, S. and Zain, M. and Abdul Wahab, E. A. (2016), "Political connections, institutional investors and dividend payouts in Malaysia", Pacific Accounting Review, Vol. 28 No. 2, pp. 153-179.

Berkman, H. and Galpoththage, V. (2016), "Political connections and firm value: an analysis of listed firms in Sri Lanka”, Pacific Accounting Review, Vol. 28 No. 1, pp. 92-106.

Bertrand, M., Kramarz, F., Schoar, A. and Thesmar, D. (2018), "The cost of political connections", Review of Finance, Vol. 22 No. 3, pp. 849-876.

Blau, B. M., Brough, T. J. and Thomas, D. W. (2013), "Corporate lobbying, political connections, and the bailout of banks", Journal of Banking \& Finance, Vol. 37 No. 8, pp. 30073017.

Bliss, M. A. and Gul, F. A. (2012), "Political connection and cost of debt: some Malaysian evidence", Journal of Banking \& Finance, Vol. 36 No. 5, pp. 1520-1527.

Boubakri, N., Cosset, J. C. and Saffar, W. (2012a), "The impact of political connections on firms' operating performance and financing decisions", Journal of Financial Research, Vol. 35 No. 3, pp. 397-423.

Boubakri, N., Guedhami, O., Mishra, D. and Saffar, W. (2012b), "Political connections and the cost of equity capital”, Journal of Corporate Finance, Vol. 18 No. 3, pp. 541-559.

Boubakri, N., El Ghoul, S., Guedhami, O. and Megginson, W.L., (2018), "The market value of government ownership", Journal of Corporate Finance, Vol. 50, pp. 44-65.

Chaney, P. K., Faccio, M. and Parsley, D. (2011), "The quality of accounting information in politically connected firms", Journal of Accounting and Economics, Vol. 51 No.1-2, pp. 5876.

Cheema, M. U., Munir, R. and Su, S. (2016), "Political connections and organizational performance: evidence from Pakistan", International Journal of Accounting \& Information Management, Vol. 24 No. 4, pp. 321-338. 
Chekir, H. and Diwan, I. (2013), "Crony capitalism in Egypt", Working Paper 250, Centre for International Development at Harvard University.

Chen, C. J., Ding, Y. and Kim, C. (2010), "High- level politically connected firms, corruption, and analyst forecast accuracy around the world", Journal of International Business Studies, Vol. 41 No. 9, pp. 1505-1524.

Chen, C. J., Li, Z., Su, X. and Sun, Z. (2011), "Rent-seeking incentives, corporate political connections, and the control structure of private firms: Chinese evidence", Journal of Corporate Finance, Vol. 17 No. 2, pp. 229-243.

Chen, Y. J., Luo, D. and Li, W. (2014), "Political connections, entry barriers, and firm performance", Chinese Management Studies, Vol. 8 No. 3, pp. 473-486.

Chung, C. Y., Byun, J. H. and Young, J., (2019), "Corporate political ties and firm value: comparative analysis in the Korean market”, Sustainability, Vol. 11 No. 2, pp. 327-352.

Cooper, M. J., Gulen, H. and Ovtchinnikov, A. V. (2010), "Corporate political contributions and stock returns", The Journal of Finance, Vol. 65 No. 2, pp. 687-724.

Correia, M. M. (2014), "Political connections and SEC enforcement", Journal of Accounting and Economics, Vol. 57 No. 2-3, pp. 241-262.

Domadenik, P., Prašnikar, J. and Svejnar, J. (2015), "Political connectedness, corporate governance, and firm performance”, Journal of Business Ethics, Vol. 135 No. 2, pp. 1-18.

Du, J. and Girma, S. (2010), "Red capitalists: political connections and firm performance in China”, KYKLOS, Vol. 63 No. 4, pp. 530- 545.

Faccio, M. (2006), "Politically connected firms", The American Economic Review, Vol. 96 No. 1, pp. 369-386.

Faccio, M. (2010), "Differences between politically connected and non-connected firms: a cross-country analysis", Financial Management, Vol. 39 No. 3, pp. 905-928.

Faccio, M. and Parsley, D. C., (2009), "Sudden deaths: taking stock of geographic ties", Journal of Financial and Quantitative Analysis, 44 (3), pp.683-718.

Faccio, M., Masulis, R. W., and McConnell, J. (2006), "Political connections and corporate bailouts", The Journal of Finance, Vol. 61 No. 6, pp. 2597-2635.

Fan, J. P., Wong, T. J. and Zhang, T. (2007), "Politically connected CEOs, corporate governance, and post-IPO performance of China's newly partially privatized firms", Journal of Financial Economics, Vol. 84 No. 2, pp. 330-357.

Fisman, R. (2001), "Estimating the value of political connections", The American Economic Review, Vol. 91 No. 4, pp. 1095-1102.

Francis, D., Hussain, S. and Schiffbauer, M. (2018), "Do politically connected firms innovate, contributing to long-term economic growth", Policy Research Working Paper 8502, World Bank, Macroeconomics, Trade and Investment Global Practice June.

Gilabert, J. C. (2011), "Politically connected firms: the case of Spain", working paper, UniversitatAutonoma de Barcelona, Universidad Pùblica de Navarra and Universitat de les IllesBalears, September.

Goldman, E., Rocholl, J. and So, J. (2009), "Do political connected boards affect firm value?", Review of Financial Studies, Vol. 22 No. 6, pp. 2331-2360. 
Goldman, E., Rocholl, J. and So, J. (2013), "Politically connected boards of directors and the allocation of procurement contracts", Review of Finance, Vol. 17 No. 6, pp. 1-32.

Houston, J. F., Jiang, L., Lin, C. and Ma, Y. (2014), "Political connections and the cost of bank loans", Journal of Accounting Research, Vol. 52 No.1, pp. 193-243.

Houston, R., Maslar, D. A. and Pukthuanthong, K. (2017), "Political connections, government procurement contracts, and the cost of debt", Working paper, Scott College of Business, Indiana State University, 31 July.

Jackowicz, K., Kozlowski, L. and Mielcarz, P. (2014), "Political connections and operational performance of non-financial firms: new evidence from Poland", Emerging Markets Review, Vol. 20 No. (3), pp. 109-135.

Jetter, M., Agudelo, A. M. and Hassan, A. R. (2015), "The effect of democracy on corruption: income is key", World Development, Vol. 74 No. 10, pp. 286-304.

Khwaja, A. I. and Mian, A. (2011), "Rent seeking and corruption in financial markets", The Annual Review of Economics, Vol. 3 No. 1, pp. 579- 600.

Kienle, Eberhard (2004). "Reconciling Privilege and Reform." In Networks of Privilege:

Rethinking the

Kim, C. F. and Zhang, L. (2016), "Corporate political connections and tax aggressiveness", Contemporary Accounting Research, Vol. 33 No. 1, pp. 78-114.

Lau, Y. W. and Tong, C. Q, (2008), "Are Malaysian government-linked companies (GLCs) creating value", International Applied Economics and Management Letters, Vol. 1 No. 1, pp. 9-12.

Li, H., Meng, L., Wang, Q. and Zhou, L. A. (2008), "Political connections, financing and firm performance: evidence from Chinese private firms", Journal of Development Economics, Vol. 87, No. 2, pp. 283-299.

Loewe, M. (2013), "Industrial policy in Egypt 2004-2011”, Working paper, German Development Institute /DeutschesInstitutfürEntwicklungspolitik (DIE), 16 July.

Lu, J. Y. and Choi, S. J. (2013), "Corporate political activities and firm growth in emerging economies", AIM Working Paper Series No. 14-005, Asian Institute of Management, Business and Development Research, Makati.

Maaloul, A., Chakroun, R. and Yahyaoui, S. (2018), "The effect of political connections on companies' performance and value: evidence from Tunisian companies after the revolution", Journal of Accounting in Emerging Economies, Vol. 8 No. 2, pp. 185-204.

Menozzi, A., Urtiaga, M. G. and Vannoni, D. (2011), "Board composition, political connections and performance in state-owned enterprises", Industrial and Corporate Change, Vol. 21 No. 3, pp. 671-698.

Mohammed, N.F., Ahmed, K., and Ji, X.D. (2017), "Accounting conservatism, corporate governance and political connections", Asian Review of Accounting. Vol. 25 No. 2, pp. 288318.

Mohieldin, M., Hussein, K. and Rostom, A. (2019), "On financial development and economic growth in Egypt", Journal of Humanities and Applied Social Sciences, Vol. 1 No. 2, pp. 70-86.

Noll, J. (2019), "Fighting corruption or protecting the regime? Egypt's administrative control authority", Project on Middle East Democracy, Rhode Island Avenue, NW, February. 
Pérez, S. G., Sánchez, C. B. and Martín, D. J. C. (2015), "Politically connected firms in Spain", Business Research Quarterly, Vol. 18 No. 4, pp. 230-245.

Sfakianakis, J. (2004), "The whales of the Nile: networks, businessmen and bureaucrats during the era of privatization in Egypt", In Heydemann, S. (Ed.), Networks of Privilege in the Middle East: The Politics of Economic Reform Revisited, Palgrave Macmillan, New York, pp. 77-100.

Shleifer, A. and Vishny, R. W. (1994), "Politicians and firms", The quarterly Journal of Economics, Vol. 109 No. 4, pp. 995-1025.

Smith, G. D. (2016), "US political corruption and firm financial policies", Journal of Financial Economics, Vol. 121, No. 1, pp. 350-367.

Song, M., Ai, H. and Li, X. (2015), "Political connections, financing constraints, and the optimization of innovation efficiency among China's private enterprises", Technological Forecasting and Social Change, Vol. 92 No. 3, pp. 290-299.

Su, Z. Q. and Fung, H. G. (2013), "Political connections and firm performance in Chinese companies", Pacific Economic Review, Vol. 18 No. 3, pp. 283-317.

Tahoun, A. (2014), "The role of stock ownership by US members of congress on the market for political favors", Journal of Financial Economics, Vol. 111 No. 1, pp. 86-110.

Tu, G., Lin, B. and Liu, F. (2013), "Political connections and privatization: evidence from China”, Journal of Accounting and Public Policy, Vol. 32 No. 2, pp. 114-135.

Wang, F., Xu, L., Zhang, J. and Shu, W. (2018), "Political connections, internal control and firm value: evidence from China's anti-corruption campaign", Journal of Business Research, Vol. 86 No. 5, pp. 53-67.

Weigelt, K. and Camerer, C. (1988), "Reputation and corporate strategy: a review of recent theory and applications", Strategic Management Journal, Vol. 9 No. 5, pp. 443- 454.

Wong, W. Y. and Hooy, C. W. (2018), "Do types of political connection affect firm performance differently?”, Pacific-Basin Finance Journal, Vol. 51 No. 5, pp. 297-317.

Wu, W., Wu, C. and Rui, O. M. (2012a), "Ownership and the value of political connections: evidence from China”, European Financial Management, Vol. 18 No. 4, pp. 695-729.

Wu, W., Wu, C., Zhou, C. and Wu, J. (2012b), "Political connections, tax benefits and firm performance: evidence from China", Journal of Accounting and Public Policy, 31 No. 3, pp. 277-300.

$\mathrm{Xu}$, N., Xu, X. and Yuan, Q. (2013), "Political connections, financing friction, and corporate investment: evidence from Chinese listed family firms", European Financial Management, Vol. 19, No. 4, pp. 675-702.

Yingling, M. P. and Arafa, M. A. (2013), “After the revolution: Egypt's changing forms of corruption", University of Baltimore Journal of International Law, Vol. 2 No. 3, pp. 23-62. 
Table (1): Sample selection process and final sample distribution by sector

\begin{tabular}{|lcc|}
\hline & Number of firms & $\begin{array}{c}\text { Number of observations } \\
\text { (2014-2017) }\end{array}$ \\
\hline Initial Sample & 100 firms & 400 \\
(-) Finance and Insurance institutions & $(22)$ & $(88)$ \\
(-) firms with missing data & $(7)$ & $(28)$ \\
= Final Sample & 71 & 284 \\
\hline
\end{tabular}

Final sample Distribution by Sector:

\begin{tabular}{|lccc|}
\hline Sector & Number of firms & $\begin{array}{c}\text { Number of } \\
\text { observations }\end{array}$ & \% \\
\hline Food \& beverage & 11 & 44 & $15.5 \%$ \\
Real estate & 11 & 44 & $15.5 \%$ \\
Construction \& materials & 9 & 36 & $12.7 \%$ \\
Industrial goods, services \& & 7 & 28 & $9.9 \%$ \\
automobiles & & & \\
Chemicals & 7 & 28 & $9.9 \%$ \\
Basic resources & 6 & 24 & $8.5 \%$ \\
Personal \& household & 6 & 24 & $8.5 \%$ \\
products & & & \\
Travel and leisure & 5 & 20 & $7 \%$ \\
Telecommunications & 2 & 8 & $2.8 \%$ \\
Healthcare \& pharmaceuticals & 2 & 8 & $2.8 \%$ \\
Media & 1 & 4 & $1.4 \%$ \\
Retail & 1 & 4 & $1.4 \%$ \\
Oil and gas & 2 & 8 & $2.8 \%$ \\
Technology & 1 & 4 & $1.4 \%$ \\
Total & $\mathbf{7 1}$ & $\mathbf{2 8 4}$ & $\mathbf{1 0 0 \%}$ \\
\hline
\end{tabular}


Table 2: Variables Definitions

\begin{tabular}{|c|c|c|}
\hline Variable name & Variable Definitions & Sources \\
\hline \multicolumn{3}{|c|}{ Dependent variables } \\
\hline$R O A$ & $\begin{array}{l}\text { Return on assets, which is calculated based on the net } \\
\text { income before extraordinary items divided by total assets } \\
\text { of a firm in year } t \text {. }\end{array}$ & $\begin{array}{l}\text { Fisman (2001); Ang et al. } \\
\text { (2013); Berkman and } \\
\text { Galpoththage (2016); } \\
\text { Maaloul et al. (2018). }\end{array}$ \\
\hline$R O E$ & $\begin{array}{l}\text { Return on equity, which is calculated based on the net } \\
\text { income before extraordinary items divided by } \\
\text { shareholders' equity of a firm in year } t \text {. }\end{array}$ & $\begin{array}{l}\text { Ang et al. }(2013) \\
\text { Berkman and } \\
\text { Galpoththage (2016); } \\
\text { Cheema et al. }(2016)\end{array}$ \\
\hline Tobin's $Q$ & $\begin{array}{l}\text { The natural logarithm of the ratio of the market value to } \\
\text { the book value of total assets of a firm in year } t \text {, as } \\
\text { follows. } \\
\left.\qquad \begin{array}{c}\text { (number of outstanding shares } \times \text { stock price at the year end }) \\
+ \\
\text { (book value of total liabilities) }\end{array}\right)\end{array}$ & $\begin{array}{l}\text { Ang et al. (2013); Su and } \\
\text { Fung (2013); Pérez et al. } \\
\text { (2015); Maaloul et al. } \\
\text { (2018). }\end{array}$ \\
\hline \multicolumn{3}{|c|}{ Independent variables } \\
\hline $\mathrm{PC}_{1}$ & $\begin{array}{l}\text { Politically connected firms through top officers, which is } \\
\text { measured as a dummy variable equals to } 1 \text { if one of the } \\
\text { firm's top officers (e.g., chairman, secretary, board of } \\
\text { directors' members, CEO) is one of a current or former top } \\
\text { government officials (e.g., minister or a member of the } \\
\text { national parliament), senior military personnel, a member } \\
\text { of political party, or has a family ties with those politicians, } \\
\text { and } 0 \text { otherwise. }\end{array}$ & $\begin{array}{l}\text { Faccio (2006); Fan et al. } \\
\text { (2007); Su and Fung } \\
\text { (2013); Ang et al. (2013); } \\
\text { Maaloul et al. (2018). }\end{array}$ \\
\hline $\mathrm{PC}_{2}$ & $\begin{array}{l}\text { Politically connected firms through business owners, which } \\
\text { is measured as a dummy variable equals to } 1 \text { if one of large } \\
\text { shareholders in the firm, controlling at least } 10 \% \text { of voting } \\
\text { rights, is a current or former top government officials, e.g., } \\
\text { minister or a member of the national parliament or senior } \\
\text { military personnel, member of political party, or has a } \\
\text { family ties with politicians, and } 0 \text { otherwise. }\end{array}$ & $\begin{array}{l}\text { Faccio (2006); Berkman } \\
\text { and Galpoththage (2016); } \\
\text { Wong and Hooy (2018); } \\
\text { Chung et al. (2019). }\end{array}$ \\
\hline $\mathrm{PC}_{3}$ & $\begin{array}{l}\text { Politically connected firms through government } \\
\text { ownership, which is measured as a dummy variable equals } \\
\text { to } 1 \text { if the government controlling at least } 10 \% \text { of firm } \\
\text { shares, and } 0 \text { otherwise. }\end{array}$ & $\begin{array}{l}\text { Wu et al. (2012a); Su and } \\
\text { Fung (2013); Ang et al. } \\
\text { (2013); Wong and Hooy } \\
\text { (2018). }\end{array}$ \\
\hline \multicolumn{3}{|c|}{ Control variables } \\
\hline Size & $\begin{array}{l}\text { Firm size, which is calculated based on the natural } \\
\text { logarithm of total assets of a firm in year } t \text {. }\end{array}$ & $\begin{array}{l}\text { Jackowicz et al. (2014); } \\
\text { Boubakri et al. (2012a); } \\
\text { Wong and Hooy (2018). }\end{array}$ \\
\hline$L E V$ & $\begin{array}{l}\text { Firm leverage, which is calculated based on the total debts } \\
\text { divided by total assets of a firm in year } t \text {. }\end{array}$ & $\begin{array}{l}\mathrm{Su} \text { and Fung (2013); } \\
\text { Wong and Hooy (2018); } \\
\text { Maaloul et al. (2018). }\end{array}$ \\
\hline Growth & $\begin{array}{l}\text { Firm growth, which is calculated based on the percentage } \\
\text { changes in net sales of a firm in years } t \text { and } t-1 \text {. }\end{array}$ & $\begin{array}{l}\mathrm{Su} \text { and Fung (2013); } \\
\text { Cheema et al. (2016); } \\
\text { Wang et al. (2018); Wong } \\
\text { and Hooy (2018). }\end{array}$ \\
\hline
\end{tabular}


Table 3: Descriptive statistics $(N=284)$

Panel A: Distribution of politically connected firms by $P C_{S}$ type

\begin{tabular}{|l|c|c|c|c|}
\hline \multirow{2}{*}{} & \multicolumn{2}{|c|}{ Connected firms' observations } & Unconnected firms' observations \\
\cline { 2 - 5 } & Numbers & \% & Numbers & \% \\
\hline $\mathrm{PC}_{1}$ & 207 & $72.9 \%$ & 77 & $27.1 \%$ \\
$\mathrm{PC}_{2}$ & 58 & $20.4 \%$ & 226 & $79.6 \%$ \\
$\mathrm{PC}_{3}$ & 133 & $46.8 \%$ & 151 & $53.2 \%$ \\
\multicolumn{3}{|c|}{23} & \multicolumn{3}{c}{$8 \%$} \\
\hline
\end{tabular}

Panel B: Distribution of politically connected firms by year

\begin{tabular}{|c|c|c|c|c|}
\hline \multirow{2}{*}{} & \multicolumn{2}{|c|}{ Connected firms' observations } & \multicolumn{2}{c|}{ Unconnected firms' observations } \\
\cline { 2 - 5 } & Numbers & \% & Numbers & \% \\
\hline PC $_{\mathbf{1}}$ & & & & \\
2014 & 50 & $70.42 \%$ & 21 & $29.58 \%$ \\
2015 & 51 & $71.83 \%$ & 20 & $28.17 \%$ \\
2016 & 53 & $74.65 \%$ & 18 & $25.35 \%$ \\
2017 & 53 & $74.65 \%$ & 18 & $25.35 \%$ \\
PC $_{2}$ & & & & \\
2014 & 14 & $19.72 \%$ & 57 & $80.28 \%$ \\
2015 & 15 & $21.13 \%$ & 56 & $78.87 \%$ \\
2016 & 15 & $1.13 \%$ & 56 & $78.87 \%$ \\
2017 & 14 & $4.72 \%$ & 57 & $80.28 \%$ \\
PC $_{3}$ & & $46.48 \%$ & 38 & \\
2014 & 33 & $46.48 \%$ & 38 & $53.52 \%$ \\
2015 & 33 & $46.48 \%$ & 38 & $53.52 \%$ \\
2016 & 33 & $47.89 \%$ & 37 & $53.52 \%$ \\
2017 & 34 & &
\end{tabular}

Panel C: Distribution of politically connected firms by industry

\begin{tabular}{|l|c|c|c|c|c|c|}
\hline \multirow{2}{*}{ Sector } & \multicolumn{6}{|c|}{ Connected firms' observations } \\
\cline { 2 - 8 } & $\mathbf{P C}_{\mathbf{1}}$ & $\mathbf{\%}$ sample & $\mathbf{P C}$ & $\mathbf{\%}$ sample & $\mathbf{P C}_{\mathbf{3}}$ & $\mathbf{\%}$ sample \\
\hline Food and beverage & 24 & $11.59 \%$ & 10 & $17.24 \%$ & 16 & $12.03 \%$ \\
Real estate & 36 & $17.39 \%$ & 12 & $20.69 \%$ & 12 & $9.02 \%$ \\
Construction and materials & 25 & $12.08 \%$ & 4 & $6.90 \%$ & 16 & $12.03 \%$ \\
Industrial goods and services & 28 & $13.53 \%$ & 8 & $13.79 \%$ & 16 & $12.03 \%$ \\
Chemicals & 12 & $5.80 \%$ & 4 & $6.90 \%$ & 24 & $18.05 \%$ \\
Basic resources & 14 & $6.76 \%$ & 8 & $13.79 \%$ & 12 & $9.02 \%$ \\
Personal and household & 20 & $9.66 \%$ & 4 & $6.90 \%$ & 13 & $9.77 \%$ \\
products & & & & & & \\
Travel and leisure & 16 & $7.73 \%$ & 8 & $13.79 \%$ & 8 & $6.02 \%$ \\
and utilities & & & & & & \\
Telecommunications & 8 & $3.86 \%$ & 0 & $0.00 \%$ & 4 & $3.01 \%$ \\
Healthcare and pharmaceuticals & 8 & $3.86 \%$ & 0 & $0.00 \%$ & 0 & $0.00 \%$ \\
Media & 4 & $1.93 \%$ & 0 & $0.00 \%$ & 4 & $3.01 \%$ \\
Retail & 0 & $0.00 \%$ & 0 & $0.00 \%$ & 4 & $3.01 \%$ \\
Oil and gas & 8 & $3.86 \%$ & 0 & $0.00 \%$ & 4 & $3.01 \%$ \\
Technology & 4 & $1.93 \%$ & 0 & $0.00 \%$ & 0 & $0.00 \%$ \\
Total & $\mathbf{2 0 7}$ & $\mathbf{1 0 0 \%}$ & $\mathbf{5 8}$ & $\mathbf{1 0 0 \%}$ & $\mathbf{1 3 3}$ & $\mathbf{1 0 0 . 0 0 \%}$ \\
\hline
\end{tabular}


Table 4: Summary statistics of the mean differences and $t$-test

Panel (A): Statistics variance between politically connected firms through top officers (PC1) and unconnected firms

\begin{tabular}{|l|c|c|c|c|c|c|}
\hline Variables & \multicolumn{2}{|c|}{ Connected firms (207) } & \multicolumn{2}{c|}{ Unconnected firms (77) } & \multirow{2}{*}{ t-test } & \multirow{2}{*}{ Sig. } \\
\cline { 1 - 4 } & Mean & SD & Mean & SD & & \\
\hline PC $_{\mathbf{1}}$ & & & & & & \\
ROA & 0.047 & 0.089 & 0.044 & 0.066 & 0.258 & 0.796 \\
ROE & 0.108 & 0.174 & 0.127 & 0.148 & -0.865 & 0.388 \\
Tobin's $Q$ & 0.346 & 0.747 & 0.236 & 0.602 & 1.154 & 0.249 \\
Size & 20.668 & 1.732 & 20.144 & 1.520 & 2.341 & $0.020^{* *}$ \\
LEV & 0.404 & 0.243 & 0.418 & 0.298 & -0.408 & 0.638 \\
Growth & -0.118 & 0.436 & -0.150 & 0.417 & 0.549 & 0.583 \\
\hline
\end{tabular}

Panel (B): Statistics variance between politically connected firms through business owners (PC2) and unconnected firms

\begin{tabular}{|l|c|c|c|c|c|c|}
\hline \multicolumn{1}{|c|}{ Variables } & \multicolumn{2}{|c|}{ Connected firms (58) } & \multicolumn{2}{c|}{ Unconnected firms (226) } & t-test & \multirow{2}{*}{ Sig. } \\
\hline & Mean & SD & Mean & SD & & \\
\hline PC $_{\mathbf{2}}$ & & & & & & \\
ROA & 0.036 & 0.068 & 0.049 & 0.087 & -1.026 & 0.306 \\
ROE & 0.063 & 0.121 & 0.126 & 0.175 & -2.560 & $0.011^{* *}$ \\
Tobin's $Q$ & 0.079 & 0.616 & 0.377 & 0.723 & -2.873 & $0.004^{* * *}$ \\
Size & 21.277 & 1.707 & 20.333 & 1.635 & 3.888 & $0.000^{* * *}$ \\
Lev & 0.369 & 0.238 & 0.418 & 0.263 & -1.279 & 0.202 \\
Growth & -0.1606 & 0.415 & -0.118 & 0.435 & -0.658 & 0.511 \\
\hline
\end{tabular}

Panel (C): Statistics variance between politically connected firms through government ownership (PC3) and unconnected firms

\begin{tabular}{|l|c|c|c|c|c|c|}
\hline Variables & \multicolumn{2}{|c|}{ Connected firms (133) } & \multicolumn{2}{c|}{ Unconnected firms (151) } & t-test & Sig. \\
\hline PC $_{\mathbf{2}}$ & Mean & SD & Mean & SD & & \\
ROA & & & & & & \\
ROE & 0.057 & 0.095 & 0.037 & 0.071 & 1.934 & $0 . .054^{*}$ \\
Tobin's $Q$ & 0.163 & 0.184 & 0.069 & 0.138 & 4.859 & $0.000^{* * *}$ \\
Size & 0.432 & 0.733 & 0.214 & 0.678 & 2.605 & $0.010^{* *}$ \\
Lev & 20.553 & 1.544 & 20.502 & 1.815 & 0.252 & 0.801 \\
Growth & 0.439 & 0.281 & 0.381 & 0.235 & 1.871 & $0.062^{*}$ \\
\hline
\end{tabular}

Notes: $P C_{1}$ is politically connected firms through top officers, $P C_{2}$ is politically connected firms through business owners, $P C_{3}$ is politically connected firms through government ownership, ROA and ROE are used to measure firm's profitability; Tobin's $Q$ is used to measure firm's market value. Table 2 shows variables definitions. ***, **, * Significant at 1, 5, and 10 percent levels, respectively. 
Table 5: Pearson correlations of variables $(N=284)$

\begin{tabular}{|lcccccccc|}
\hline & $R O A$ & $R O E$ & Tobin's $Q$ & $P C_{1}$ & $P C_{2}$ & $P_{3}$ & Size & Lev \\
\hline ROA & 1 & & & & & & \\
ROE & $0.535^{* * *}$ & 1 & & & & & \\
Tobin's $Q$ & $0.142^{* *}$ & $0.314^{* * *}$ & 1 & & & & \\
$P C_{1}$ & 0.015 & -0.051 & 0.069 & 1 & & & \\
$P C_{2}$ & -0.061 & $-0.151^{* *}$ & $-0.169^{* * *}$ & $0.309^{* * *}$ & 1 & & & \\
$P C_{3}$ & $0.114^{*}$ & $0.278^{* * *}$ & $0.153^{* * *}$ & $-0.285^{* * *}$ & $-0.475^{* * *}$ & 1 & & \\
Size & $0.219^{* * *}$ & $0.140^{* *}$ & $-0.290^{* * *}$ & $0.138^{* *}$ & $0.226^{* * *}$ & 0.015 & 1 & \\
LEV & $-0.256^{* * *}$ & $0.339^{* * *}$ & $0.265^{* * *}$ & -0.024 & -0.076 & $0.111^{*}$ & 0.003 & 1 \\
Growth & -0.084 & $-0.127^{* *}$ & 0.068 & 0.033 & -0.039 & 0.009 & $-0.142^{* *}$ & -0.087 \\
\hline
\end{tabular}

Notes: $P C_{1}$ is politically connected firms through top officers, $P C_{2}$ is politically connected firms through business owner, $P C_{3}$ is politically connected firms through government ownership, $R O A$ and $R O E$ are used to measure firm's profitability; Tobin's Q is used to measure firm's market value. Table 2 shows variables definitions. ***, **, * Significant at 1, 5, and 10 percent levels, respectively. 
Table (6): Effects of different types of PCs on profitability (ROA, ROE) and firm's market value (Tobin's $Q$ ).

\begin{tabular}{|lccc|}
\hline & $\begin{array}{c}\text { Model (1) } \\
\boldsymbol{R O A}\end{array}$ & $\begin{array}{c}\text { Model (2) } \\
\boldsymbol{R O E}\end{array}$ & $\begin{array}{c}\text { Model (3) } \\
\text { Tobin's } \boldsymbol{Q}\end{array}$ \\
\hline Intercept & $-0.219^{* * *}(-3.523)$ & $-0.366^{* * *}(-2.940)$ & $0.852^{*}(1.782)$ \\
$P C_{1}$ & $0.001(0.094)$ & $0.003(0.105)$ & $0.220^{* *}(2.384)$ \\
$P C_{2}$ & $0.001(0.094)$ & $-.007(-0.245)$ & $-0.069(-0.656)$ \\
$P C_{3}$ & $0.032^{* * *}(2.890)$ & $0.083^{* * *}(3.714)$ & $0.227^{* * *}(2.639)$ \\
Size & $0.014^{* * *}(4.583)$ & $0.017^{* * *}(2.781)$ & $-0.056^{* *}(-2.449)$ \\
LEV & $-0.074^{* * *}(-3.913)$ & $0.211^{* * *}(5.548)$ & $0.841^{* * *}(5.763)$ \\
Growth & $-0.011(-1.065)$ & $-0.029(-1.410)$ & $0.142^{*}(1.799)$ \\
Observations & 284 & 284 & 284 \\
Industry Fixed Effect & $Y e s$ & $Y e s$ & Yes \\
Year Fixed Effect & Yes & Yes & Yes \\
Adjusted R $R^{2}$ & $26.30 \%$ & $26.30 \%$ & $39.7 \%$ \\
\hline
\end{tabular}

Notes: This table shows the coefficients of regression models and t-statistics reported in parentheses. $P C_{1}$ is politically connected firms through top officers, $P C_{2}$ is politically connected firms through business owners, $P C_{3}$ is politically connected firms through government ownership, ROA and ROE are used to measure firm's profitability; Tobin's $Q$ is used to measure firm's market value. Table 2 shows variables definitions. ***, **, * Significant at 1, 5, and 10 percent levels, respectively. 
Table (7): Effect of different types of PCs on profitability (ROS) and firm's market value (MtB).

\begin{tabular}{|lcc|}
\hline & Model (1) & Model (2) \\
& ROS & MtB \\
\hline Intercept & $-0.034(-0.308)$ & $2.699^{* * *}(2.778)$ \\
$P C_{1}$ & $-0.017(-0.780)$ & $0.312^{*}(1.686)$ \\
$P C_{2}$ & $0.013(0.540)$ & $0.026(0.123)$ \\
$P C_{3}$ & $0.070^{* * *}(3.511)$ & $0.439^{* * *}(2.536)$ \\
Size & $0.018^{* * *}(3.272)$ & $-0.143^{* * *}(-3.108)$ \\
LEV & $-0.006(-0.175)$ & $0.503^{* *}(1.714)$ \\
Growth & $-0.016(-0.866)$ & $0.473^{* * *}(2.984)$ \\
Observations & 284 & 284 \\
Industry Fixed Effect & Yes & Yes \\
Year Fixed Effect & $Y e s$ & Yes \\
Adjusted R-squared & $50.9 \%$ & $54.6 \%$ \\
\hline
\end{tabular}

Notes: This table shows the coefficients of regression models and t-statistics reported in parentheses. $P C_{1}$ is politically connected firms through top officers, $P C_{2}$ is politically connected firms through business owners, $P_{3}$ is politically connected firms through government ownership, ROS is used to measure firm's profitability; MtB is used to measure firm's market value. Table 2 shows variables definitions. ***, **, * Significant at 1, 5, and 10 percent levels, respectively. 
Table (8): The moderating effects of political connections through top officers $\left(\mathrm{PC}_{1}\right)$

\begin{tabular}{|lccc|}
\hline & $\begin{array}{c}\text { Model (1) } \\
\text { ROA }\end{array}$ & $\begin{array}{c}\text { Model (2) } \\
\text { ROE }\end{array}$ & $\begin{array}{c}\text { Model (3) } \\
\text { Tobin's } \boldsymbol{Q}\end{array}$ \\
\hline Intercept & $0.0112(0.16)$ & $0.029(0.21)$ & $0.664(1.25)$ \\
$P C_{1}$ & $-0.0195(-1.01)$ & $-0.043(-1.15)$ & $-0.162(-1.13)$ \\
$P C_{2}$ & $0.0166(1.16)$ & $0.008(0.28)$ & $0.055(0.51)$ \\
$P C_{3}$ & $0.0457^{* *}(2.45)$ & $0.032(0.82)$ & $-0.196(-1.32)$ \\
Size & $0.0140^{* * *}(4.75)$ & $0.017^{* * *}(2.83)$ & $-0.054^{* *}(-2.41)$ \\
LEV & $-0.0748^{* *}(-4.01)$ & $0.210^{* * *}(5.55)$ & $0.837^{* * *}(5.86)$ \\
Growth & $-0.0117(-1.16)$ & $-0.030(-1.45)$ & $0.135^{*}(1.75)$ \\
$P C_{1} * P C_{3}$ & $0.0764^{* * *}(3.25)$ & $0.075^{*}(1.77)$ & $0.623^{* * *}(3.46)$ \\
Observations & 284 & 284 & 284 \\
Industry Fixed Effect & $Y e s$ & $Y e s$ & Yes \\
Year Fixed Effect & Yes & Yes & Yes \\
Adjusted R-squared & $28.87 \%$ & 26.71 & $42.10 \%$ \\
\hline
\end{tabular}

Notes: This table shows the coefficients of regression models and t-statistics reported in parentheses. $P C_{1}$ is politically connected firms through top officers, $P C_{2}$ is politically connected firms through business owners, $P C_{3}$ is politically connected firms through government ownership, $R O A$ and ROE are used to measure firm 's profitability; Tobin's $Q$ is used to measure firm 's market value. Table 2 shows variables definitions. ***, **, * Significant at 1, 5, and 10 percent levels, respectively. 
Table (9): The 2SLS regression results

\begin{tabular}{|c|c|c|c|c|c|}
\hline & $\begin{array}{c}\text { Model (1) } \\
\text { ROA }\end{array}$ & $\begin{array}{c}\text { Model (2) } \\
\text { ROE }\end{array}$ & $\begin{array}{c}\text { Model (3) } \\
\text { ROS }\end{array}$ & $\begin{array}{l}\text { Model (4) } \\
\text { Tobin's } Q\end{array}$ & $\begin{array}{c}\text { Model (5) } \\
\text { MtB }\end{array}$ \\
\hline Intercept & $-0.278^{* * *}(-4.187)$ & $-0.472^{* * *}(-3.477)$ & $-0.253(-1.232)$ & $0.912^{*}(1.842)$ & $3.241^{* * *}(3.249)$ \\
\hline$P C_{1}$ & $-0.000(-0.022)$ & $-0.019(-0.657)$ & $0.001(0.033)$ & $0.298^{* * *}(2.764)$ & $0.644^{* * *}(2.972)$ \\
\hline$P C_{2}$ & $-0.033^{*}(-1.772)$ & $-.058(-1.529)$ & $-0.033(-0.611)$ & $0.032(0.162)$ & $0.381(1.360)$ \\
\hline$P C_{3}$ & $0.039^{* * *}(3.255)$ & $0.073^{* * *}(2.969)$ & $0.080^{* *}(2.234)$ & $0.480^{* * *}(5.317)$ & $0.861^{* * *}(4.742)$ \\
\hline Size & $0.018^{* * *}(5.206)$ & $0.025^{* * *}(3.565)$ & $0.031^{* * *}(2.918)$ & $-0.055^{* *}(-2.151)$ & $-0.172^{* * *}(-3.360)$ \\
\hline$L E V$ & $-0.097^{* * *}(-4.844)$ & $0.180^{* * *}(4.403)$ & $-0.186^{* * *}(-3.039)$ & $0.633^{* * *}(4.236)$ & $0.174(0.579)$ \\
\hline Growth & $-0.011(-1.012)$ & $-0.025(-1.200)$ & $-0.005(-0.134)$ & $0.141^{*}(1.823)$ & $0.462^{* * *}(2.962)$ \\
\hline Observations & 284 & 284 & 284 & 284 & 284 \\
\hline Industry Fixed Effect & Yes & Yes & Yes & Yes & Yes \\
\hline Year Fixed Effect & Yes & Yes & Yes & Yes & Yes \\
\hline Adjusted R-squared & $27.9 \%$ & $24.7 \%$ & $25.2 \%$ & $44.4 \%$ & $58 \%$ \\
\hline
\end{tabular}

Notes: This table shows the coefficients of regression models and t-statistics reported in parentheses. PC ${ }_{1}$ is politically connected firms through top officers, $P_{2}$ is politically connected firms through business owners, $P C_{3}$ is politically connected firms through government ownership, ROA, ROE and ROS are used to measure firm 's profitability; Tobin's $Q$ and MtB are used measure firm's market value. Table 2 shows variables definitions. ***, **, * Significant at 1, 5, and 10 percent levels, respectively. 